Article

\title{
Facile Synthesis of Super-Microporous Titania-Alumina with Tailored Framework Properties
}

\author{
Yongfeng $\mathrm{Li}^{1,2}$, Jiaojiao $\mathrm{Su}^{2, *}$, Guiping $\mathrm{Li}^{1}$ and Xiufeng Meng ${ }^{1}$ \\ 1 New Energy Engineering, Shanxi Institute of Energy, Jinzhong 030600, China; lyf_a@foxmail.com (Y.L.); \\ mgylgp@sina.com (G.L.); mgymxf@126.com (X.M.) \\ 2 College of Chemistry and Chemical Engineering, Taiyuan University of Technology, Taiyuan 030024, China \\ * Correspondence: sujiaojiao@tyut.edu.cn; Tel.: +86-351-6018984
}

Received: 20 January 2020; Accepted: 25 February 2020; Published: 3 March 2020

check for updates

\begin{abstract}
Super-microporous material (pore size 1-2 nm) can bridge the pore size gap between the zeolites $(<1 \mathrm{~nm})$ and the mesoporous oxides $(>2 \mathrm{~nm})$. A series of super-microporous titania-alumina materials has been successfully prepared via a facile one-pot evaporation-induced self-assembly (EISA) strategy by different solvents using fatty alcohol polyoxyethylene ether (AEO-7) as the template. Moreover, no extra acid or base is added in our synthesis process. When titanium isopropylate is used as the titanium source, these materials exhibit high BET surface areas (from 275 to $396 \mathrm{~m}^{2} / \mathrm{g}$ ) and pore volumes (from 0.14 to $0.18 \mathrm{~cm}^{3} / \mathrm{g}$ ). The sample prepared using methanol as the solvent shows the largest Brunauer-Emmett-Teller (BET) surface area of $396 \mathrm{~m}^{2} / \mathrm{g}$. When tetrabutyl titanate is used as the titanium source, these materials exhibit high BET surface areas (from 282 to $396 \mathrm{~m}^{2} / \mathrm{g}$ ) and pore volumes (from 0.13 to $0.18 \mathrm{~cm}^{3} / \mathrm{g}$ ). The sample prepared using ethanol as the solvent shows the largest BET surface area of $396 \mathrm{~m}^{2} / \mathrm{g}$.
\end{abstract}

Keywords: super-microporous alumina-titania; different solvents; fatty alcohol polyoxyethylene ether; high BET surface areas

\section{Introduction}

Porous materials have received considerable attention owing to their ability to interact with atoms, ions, molecules, and nanoparticles not only at their surfaces, but throughout the bulk of the materials [1]. Therefore, the presence of pores in nanostructured materials greatly promotes their physical and chemical properties. Among these non-siliceous oxides, $\mathrm{TiO}_{2}-\mathrm{Al}_{2} \mathrm{O}_{3}$ is of interest for many applications in wide fields, such as catalysis [2-5], ceramic [6,7], gas sensor [8], solar cells $[9,10]$, and others [11]. Mixed titania-alumina oxides exhibit properties superior to those of single-metal oxides (alumina or titania). Such a mixture may broaden the range of applications available to this hybrid material. For instance, tielite $\left(\mathrm{Al}_{2} \mathrm{TiO}_{5}\right)$ is used as a potential adsorbent in the decontamination of chemical warfare agents [12], in materials for aeronautical and automotive purposes [13], and in orthopedic and dental implants [14]. The reported alumina-titania support for molybdenum dispersion used for the hydrodeoxygenation of palmitic acid exhibited excellent catalytic performance [3]. A study describes the enhanced performance of the chemical looping combustion of methane with an $\mathrm{Fe}_{2} \mathrm{O}_{3} / \mathrm{Al}_{2} \mathrm{O}_{3} / \mathrm{TiO}_{2}$ oxygen carrier [15]. Syntheses of mesoporous alumina-titania systems by different preparation methods have been reported. For example, Stacy M. Morris et al. [16] prepared mesoporous alumina-titania materials over a wide range of compositions by the self-assembly of $\mathrm{Al}$ and Ti isopropoxides and a triblock copolymer structure-directing agent. Liu Erming et al. [17] synthesized a series of macro-mesoporous titania/alumina core-shell materials in an oil/water interface. Guo Changyou et al. [18] synthesized a mesoporous $\mathrm{Al}_{2} \mathrm{O}_{3}-\mathrm{TiO}_{2}$ composite oxide using solvothermal method in a benzyl alcoholeoleyl amine system. However, little work has been carried out on the 
preparation of super-microporous (pore size 1-2 $\mathrm{nm}$ ) titania-alumina mixed oxides. The materials in this pore size range could bridge the pore size gap between the zeolites $(<1 \mathrm{~nm})$ and the mesoporous oxides $(>2 \mathrm{~nm})$. Such materials exhibit the potential of size and shape selectivity for those organic molecules that are too large to access into the pores of microporous zeolites and zeolite-like materials $[19,20]$.

In this research, a series of super-microporous titania-alumina materials (pore size 1-2 $\mathrm{nm}$ ) were prepared through the evaporation-induced selfassembly (EISA) method using titanium isopropylate or tetrabutyl titanate as the Ti source and aluminum nitrate nonahydrate as the $\mathrm{Al}$ source. There was no acid or base addition during the whole preparation process. By varying the solvent used among methanol, ethanol, 1-butanol, isobutanol, or 1-octanol, we successfully obtained titania-alumina materials with tailored framework properties.

\section{Materials and Methods}

\subsection{Chemicals}

Fatty alcohol polyoxyethylene ether AEO-7 (Mav = 575-605, $\mathrm{RO}\left(\mathrm{C}_{2} \mathrm{H}_{4} \mathrm{O}\right)_{n} \mathrm{H}, \mathrm{n}=7$ ) was purchased from BASF (China) co., LTD. Shanghai branch. Aluminum nitrate nonahydrate, anhydrous ethanol, and tetrabutyl titanate were obtained from Tianjin Chemical Reagent Co. Titanium isopropylate was purchased from Shanghai Aladdin Biological Technology Co., Ltd. All the chemicals were of analytical grade and used as received without further purification.

\subsection{Preparation of Super-Microporous Titania-Alumina Materials}

In a typical synthesis, $2.0 \mathrm{~g}$ of fatty alcohol polyoxyethylene ether AEO-7 was dissolved in $20 \mathrm{~mL}$ of waterless ethanol at room temperature. Then, $5 \mathrm{mmol}$ aluminum nitrate nonahydrate and $5 \mathrm{mmol}$ titanium isopropylate or tetrabutyl titanate were added. Upon rapid stirring at room temperature for least $2 \mathrm{~h}$, the resulting homogeneous sol was transferred to a petri dish and underwent solvent evaporation at $45{ }^{\circ} \mathrm{C}$ for two days and at $100{ }^{\circ} \mathrm{C}$ for one day. The final solid products were heated at $400{ }^{\circ} \mathrm{C}$ for $5 \mathrm{~h}$ to remove the organic template and named as MTA. The as-prepared super-microporous titania-alumina samples were labeled, starting with a prefix of MTA followed by the type of solvent (M, E, B, IB, and O, which refer to methanol, ethanol, 1-butanol, isobutanol, and 1-octanol, respectively), then titanium precursors ( $\mathrm{i}$ and $\mathrm{b}$, which refer to titanium isopropoxide and tetrabutyl titanate), and finally calcination temperature. For example, MTA-M-i-400 refers to super-microporous titania-alumina prepared from titanium isopropoxide with methanol solvent calcined at $400{ }^{\circ} \mathrm{C}$ for $5 \mathrm{~h}$. High-temperature treatment $\left(550^{\circ} \mathrm{C}\right.$ and $\left.750{ }^{\circ} \mathrm{C}\right)$ was carried out in air for $1 \mathrm{~h}$ with a temperature ramp of $10^{\circ} \mathrm{C} / \mathrm{min}$.

\subsection{Characterization}

Powder X-ray diffraction (XRD) measurements were performed using a Shimadzu XRD-6000 diffractometer made in Japan using Ni-filtered $\mathrm{Cu} \mathrm{K \alpha}(0.154 \mathrm{~nm})$ radiation. $\mathrm{N}_{2}$ adsorption/desorption isotherms at $77 \mathrm{~K}$ were measured on a Quantachrome QUADRASORB SI instrument. The Brunauer-Emmett-Teller (BET) method was used to calculate the specific surface area. The microporous structure was obtained from the t-plot analysis of the adsorption branch of the isotherm. The pore size distribution was calculated using the density functional theory (DFT) method pore size model applied to the adsorption branch of the isotherm. Total pore volumes were obtained at pressure 0.95 [21,22]. Micropore volumes were obtained from the t-plot method at a pressure of 0.2-0.5. Thermogravimetric-differential scanning calorimeter (TG-DSC) analysis was conducted on a NETZSCH (STA449F3) instrument made in Germany.

\section{Results and Discussions}

Figure 1 presents the TG-DSC pattern of the obtained precursor without removal of the template when tetrabutyl titanate and ethanol are used as the titanium source and solvent. The endothermic 
peak at $180{ }^{\circ} \mathrm{C}$ is attributed to the evaporation of water and ethanol in the gel. The more prominent thermal event located in the $200-400{ }^{\circ} \mathrm{C}$ temperature range is attributed partly to the remaining water included in the pores and mostly from the decomposition and oxidation of the template.

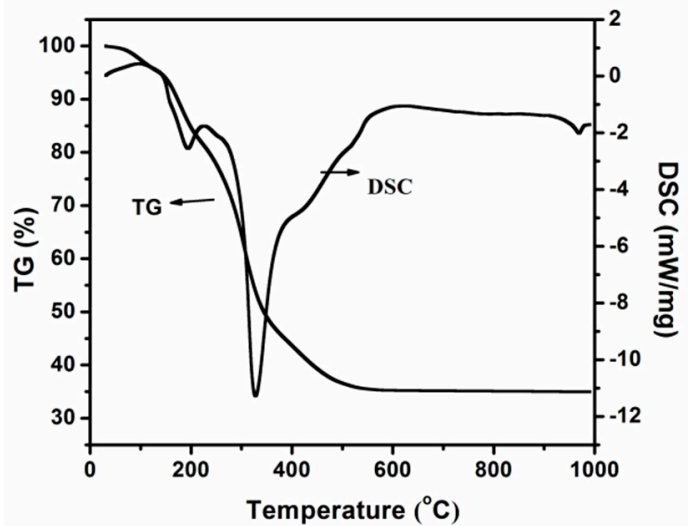

Figure 1. Thermogravimetric-differential scanning calorimeter (TG-DSC) curves of the obtained precursor when tetrabutyl titanate and ethanol are used as titanium source and solvent.

The nitrogen adsorption-desorption isotherms and the corresponding pore size distribution curves for MTA-400 samples using different solvents and titanium sources are displayed in Figures 2 and 3. The detailed textural properties are listed in Table 1. It can be seen that all samples calcinated at $400{ }^{\circ} \mathrm{C}$ exhibit a typical type I isotherm with no distinct hysteresis loop, thus indicating the presence of micropores. All these samples show narrow pore size distribution around 1-2 nm. It is also observed that there is no significant relation between porous structure type and solvent. BET surface areas does not have a linear relationship with the solvent. When ethanol is used as the solvent, MTA-E-b has the bigger BET surface area among them. The isotherm obtained using MTA-E-b, yields a surface area of $396 \mathrm{~m}^{2} / \mathrm{g}$ of which $377 \mathrm{~m}^{2} / \mathrm{g}$ in the form of micropores. The surface area of MTA-IB-b is the smallest. When titanium isopropylate is used as titanium source, MTA-M-i exhibits a BET surface area of $396 \mathrm{~m}^{2} / \mathrm{g}$ area and a microporous surface area of $375 \mathrm{~m}^{2} / \mathrm{g}$, which are much larger than other sample. The physisorption measurements reveal the largest BET surface area when methanol is used as the solvent.
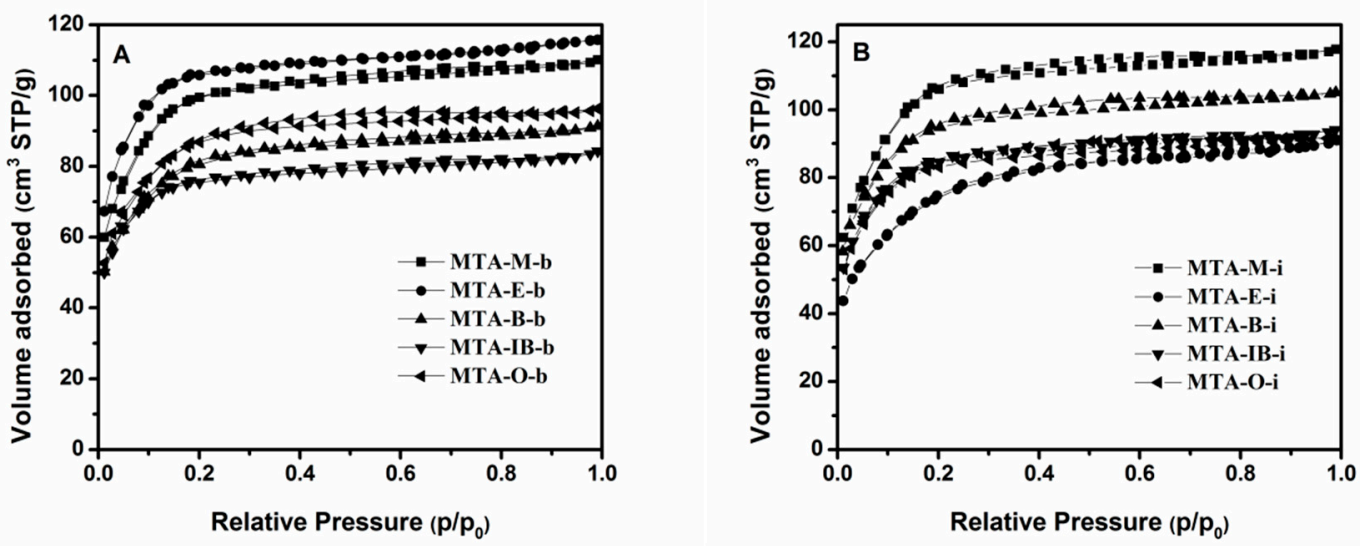

Figure 2. $\mathrm{N}_{2}$ adsorption-desorption isotherms of samples MTA-b (A) and MTA-i (B) calcined at $400{ }^{\circ} \mathrm{C}$. 

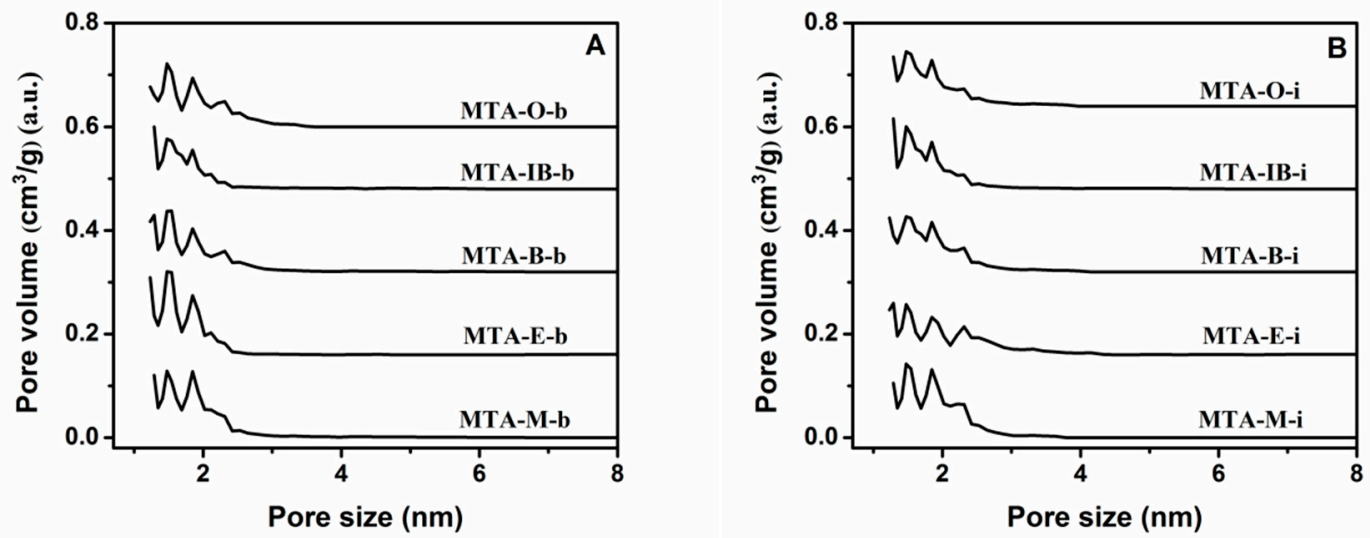

Figure 3. The corresponding pore size distribution curves of samples MTA-b (A) and MTA-i (B) calcined at $400{ }^{\circ} \mathrm{C}$. For clarity, the pore size distributions curves of MTA-E-b/MTA-E-i, MTA-B-b/MTA-B-i, MTA-IB-b/MTA-IB-i, MTA-O-b/MTA-O-i are offset along the $Y$-axis by $0.16,0.32,0.48$, and 0.64 $\mathrm{cm}^{3} / \mathrm{g}$, respectively.

Table 1. Brunauer-Emmett-Teller (BET) surface areas and pore structures of various samples calcined at $400{ }^{\circ} \mathrm{C}$.

\begin{tabular}{cccccc}
\hline Samples & $\mathbf{S}_{\text {BET }}\left(\mathbf{m}^{\mathbf{2}} / \mathbf{g}\right)$ & $\mathbf{S}_{\text {mic }}\left(\mathbf{m}^{\mathbf{2}} / \mathbf{g}\right)$ & $\mathbf{V}_{\text {total }}\left(\mathbf{c m}^{\mathbf{3}} / \mathbf{g}\right)$ & $\mathbf{V}_{\text {mic }}\left(\mathbf{c m}^{\mathbf{3}} / \mathbf{g}\right)$ & Pore Size $(\mathbf{n m})$ \\
\hline MTA-M-b & 370 & 350 & 0.17 & 0.15 & 1.5 \\
MTA-E-b & 396 & 377 & 0.18 & 0.16 & 1.5 \\
MTA-B-b & 294 & 277 & 0.14 & 0.12 & 1.5 \\
MTA-IB-b & 282 & 267 & 0.13 & 0.11 & 1.3 \\
MTA-O-b & 319 & 305 & 0.15 & 0.13 & 1.5 \\
MTA-M-i & 396 & 375 & 0.18 & 0.16 & 1.5 \\
MTA-E-i & 275 & 251 & 0.14 & 0.11 & 1.5 \\
MTA-B-i & 346 & 327 & 0.16 & 0.14 & 1.5 \\
MTA-IB-i & 309 & 292 & 0.15 & 0.13 & 1.3 \\
MTA-O-i & 303 & 286 & 0.14 & 0.12 & 1.5
\end{tabular}

Note: $\mathrm{S}_{\mathrm{BET}}, \mathrm{S}_{\mathrm{mic}}, \mathrm{V}_{\text {total }}$, and $\mathrm{V}_{\mathrm{mic}}$ are the $\mathrm{BET}$ surface areas, microporous surface areas, total pore volumes, and microporous volumes, respectively.

XRD results show that all samples calcined at $400{ }^{\circ} \mathrm{C}$ (not shown) are amorphous without the presence of any crystalline alumina and/or titania phases, suggesting that the extremely homogeneous super-microporous titania-alumina nanomaterials are formed. With the increase of quenching temperature, some samples begin to show crystallinity (as confirmed by wide angle powder XRD patterns shown in Figure 4) at the calcination temperature $550^{\circ} \mathrm{C}$. Several relatively weak diffraction peaks at $2 \theta=25.3^{\circ}, 38.5^{\circ}, 48^{\circ}, 55.1^{\circ}$ and $62.6^{\circ}$ are observed, which could be indexed as the anatase phase of titania. XRD results show that sample MTA-IB-b and MTA-M-i are crystalline, consisting only of anatase titania without any traces of crystalline alumina. When the solvent is ethanol, XRD patterns of the sample show quite broad and weak diffraction peaks, which suggests that the anatase titania crystal size is extremely small. However, the materials synthesized with other solvents are still amorphous. When the temperature is up to $750{ }^{\circ} \mathrm{C}$ (in Figure 5), all the samples are crystalline. 

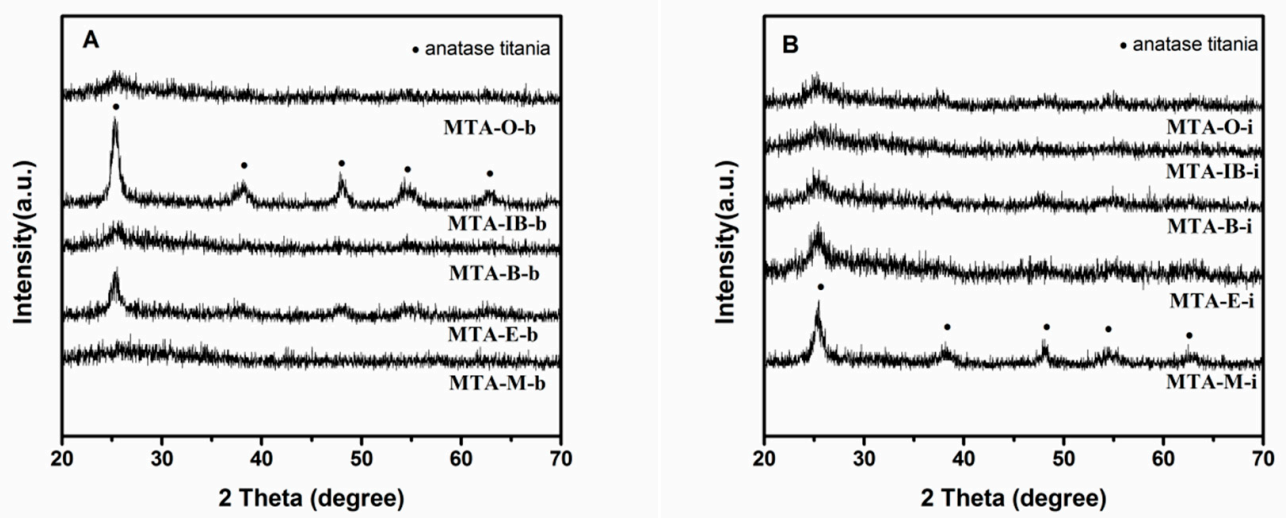

Figure 4. XRD patterns of samples MTA-b (A) and MTA-i (B) after calcination at $550{ }^{\circ} \mathrm{C}$.
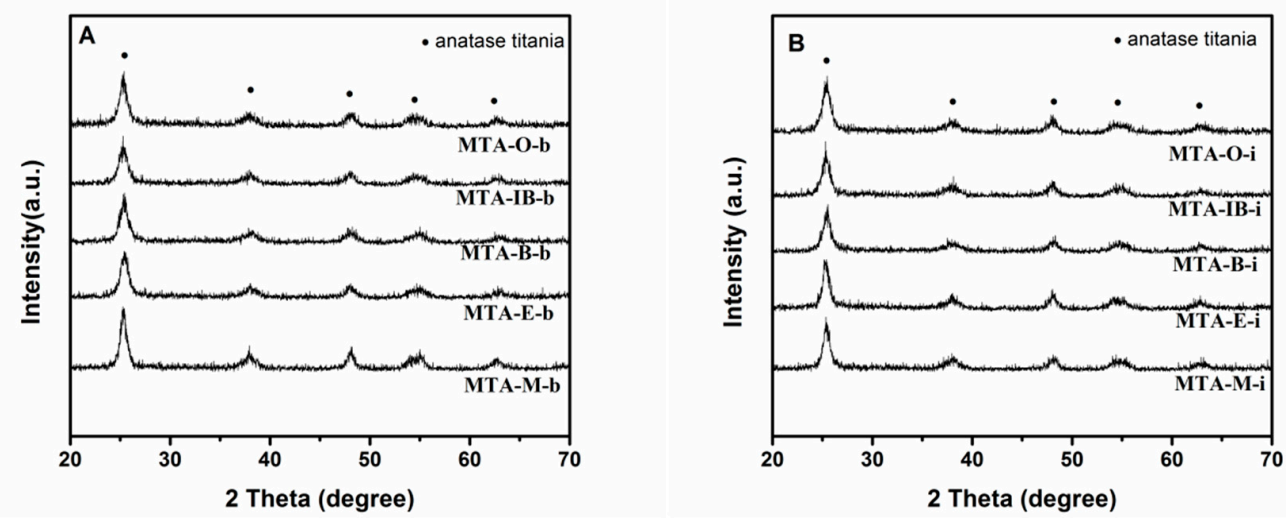

Figure 5. XRD patterns of samples MTA-b (A) and MTA-i (B) after calcination at $750{ }^{\circ} \mathrm{C}$.

\section{Conclusions}

We have successfully synthesized a series of super-microporous titania-alumina materials without adding acid or base and calcining under mild conditions. It is found that the BET surface area does not have a linear relationship with the solvent. When titanium isopropylate is used as titanium source, the BET surface area of the sample prepared using methanol as the solvent is the largest at $396 \mathrm{~m}^{2} / \mathrm{g}$. When tetrabutyl titanate is used as titanium, using ethanol as the solvent presents the largest BET at $396 \mathrm{~m}^{2} / \mathrm{g}$. Most importantly, this work opens a new methodology for the preparation of porous titania-alumina materials with good textural properties.

Author Contributions: Conceptualization, Y.L. and J.S.; methodology, Y.L. and J.S.; formal analysis, Y.L., G.L., and X.M.; resources, Y.L.; data curation, J.S.; writing—original draft preparation, Y.L.; writing—review and editing, Y.L; supervision, J.S.; funding acquisition, Y.L. All authors have read and agreed to the published version of the manuscript.

Funding: This research was funded by the School Fund ZB-2018004 and the International Clean Energy Talent Program 2019 (iCET2019).

Acknowledgments: This work was supported by the School Fund ZB-2018004. Thanks for the International Clean Energy Talent Program 2019 (iCET2019).

Conflicts of Interest: The authors declare no conflict of interest.

\section{References}

1. Li, W.; Zhao, D. An overview of the synthesis of ordered mesoporous materials. Chem. Commun. 2013, 49, 943-946. [CrossRef] [PubMed]

2. Wang, L.; Wang, X.; Cheng, J.; Ning, P.; Lin, Y. Coupling catalytic hydrolysis and oxidation on $\mathrm{Mn} / \mathrm{TiO}{ }_{2}-\mathrm{Al}_{2} \mathrm{O}_{3}$ for HCN removal. Appl. Surf. Sci. 2018, 439, 213-221. [CrossRef] 
3. Vo, T.K.; Kim, W.S.; Kim, S.S.; Yoo, K.S.; Kim, J. Facile synthesis of $\mathrm{Mo} / \mathrm{Al}_{2} \mathrm{O}_{3}-\mathrm{TiO}_{2}$ catalysts using spray pyrolysis and their catalytic activity for hydrodeoxygenation. Energy Convers. Manag. 2018, 158, 92-102. [CrossRef]

4. Matsuda, A.; Kikuchi, T.; Murayama, R.; Kogure, T.; Katagiri, K.; Muto, H.; Sakai, M. Formation of photocatalytic novel oxide crystallites with $\mathrm{Al}: \mathrm{Ti}=1: 1$ in $\mathrm{Al}_{2} \mathrm{O}_{3}-\mathrm{TiO}_{2}$ gels by mechanochemical treatment. J. Nanosci. Nanotechnol. 2009, 9, 342-349. [CrossRef] [PubMed]

5. Duan, A.; Li, R.; Jiang, G.; Gao, J.; Zhao, Z.; Wan, G.; Zhang, D.; Huang, W.; Chung, K.H. Hydrodesulphurization performance of $\mathrm{NiW} / \mathrm{TiO}_{2}-\mathrm{Al}_{2} \mathrm{O}_{3}$ catalyst for ultra clean diesel. Catal. Today 2009, 140, 187-191. [CrossRef]

6. Y1lmaz, R.; Kurt, A.O.; Demir, A.; Tatlı, Z. Effects of $\mathrm{TiO}_{2}$ on the mechanical properties of the $\mathrm{Al}_{2} \mathrm{O}_{3}-\mathrm{TiO}_{2}$ plasma sprayed coating. J. Eur. Cream. Soc. 2007, 27, 1319-1323. [CrossRef]

7. Ohishi, Y.; Miyauchi, Y.; Ohsato, H.; Kakimoto, K. Controlled temperature coefficient of resonant frequency of $\mathrm{Al}_{2} \mathrm{O}_{3}-\mathrm{TiO}_{2}$ ceramics by annealing treatment. Jpn. J. Appl. Phys. 2004, 43, L749. [CrossRef]

8. Mohammadi, M.R. Semiconductor $\mathrm{TiO}_{2}-\mathrm{Al}_{2} \mathrm{O}_{3}$ thin film gas sensors derived from aqueous particulate sol-gel process. Mater. Sci. Semicond. Proc. 2014, 27, 711-718. [CrossRef]

9. Kim, J.Y.; Kang, S.H.; Kim, H.S.; Sung, Y.E. Preparation of highly ordered mesoporous $\mathrm{Al}_{2} \mathrm{O}_{3} / \mathrm{TiO}_{2}$ and its application in dye-sensitized solar cells. Langmuir 2009, 26, 2864-2870. [CrossRef]

10. Wang, W.C.; Tsai, M.C.; Yang, J.; Hsu, C.; Chen, M.J. Efficiency enhancement of nanotextured black silicon solar cells using $\mathrm{Al}_{2} \mathrm{O}_{3} / \mathrm{TiO}_{2}$ dual-layer passivation stack prepared by atomic layer deposition. ACS Appl. Mater. Interface 2015, 7, 10228-10237. [CrossRef]

11. Kim, Y.S.; Yun, S.J. Nanolaminated $\mathrm{Al}_{2} \mathrm{O}_{3}-\mathrm{TiO}_{2}$ thin films grown by atomic layer deposition. J. Cryst. Growth 2005, 274, 585-593. [CrossRef]

12. Wagner, G.W.; Procell, L.R.; Munavalli, S. ${ }^{27} \mathrm{Al},{ }^{47},{ }^{49} \mathrm{Ti},{ }^{31} \mathrm{P}$, and ${ }^{13} \mathrm{C}$ MAS NMR study of VX, GD, and HD reactions with nanosize $\mathrm{Al}_{2} \mathrm{O}_{3}$, conventional $\mathrm{Al}_{2} \mathrm{O}_{3}$ and $\mathrm{TiO}_{2}$, and aluminum and titanium metal. J. Phys. Chem. C 2007, 111, 17564-17569. [CrossRef]

13. Mas-Guindal, M.J.; Benko, E.; Rodriguez, M.A. Nanostructured metastable cermets of Ti- $\mathrm{Al}_{2} \mathrm{O}_{3}$ through activated SHS reaction. J. Alloy Compd. 2008, 454, 352-358. [CrossRef]

14. Kim, S.E.; Lim, J.H.; Lee, S.C.; Nam, S.C.; Kang, H.G.; Choi, J. Anodically nanostructured titanium oxides for implant applications. Electrochim. Acta 2008, 53, 4846-4851. [CrossRef]

15. Wu, H.C.; Ku, Y. Enhanced performance of chemical looping combustion of methane with $\mathrm{Fe}_{2} \mathrm{O}_{3} / \mathrm{Al}_{2} \mathrm{O}_{3} / \mathrm{TiO}_{2}$ oxygen carrier. RSC Adv. 2018, 8, 39902-39912. [CrossRef]

16. Morris, S.M.; Horton, J.A.; Jaroniec, M. Soft-templating synthesis and properties of mesoporous alumina-titania. Microporous Mesoporous Mater. 2010, 128, 180-186. [CrossRef]

17. Liu, E.; Vezzoli, M.; Locke, A.J.; Frost, R.L.; Martens, W.N. Fabrication of macro-mesoporous titania/alumina core-shell materials in oil/water interface. J. Colloid Interface Sci. 2014, 436, 194-203. [CrossRef]

18. Guo, C.; Shen, Z.; Hu, Q.; Wang, S.; Ling, F. The solvothermal synthesis, structure and properties of $\mathrm{Al}_{2} \mathrm{O}_{3} \cdot \mathrm{TiO}_{2}$ mesoporous material. Mater. Chem. Phys. 2015, 151, 288-294.

19. Shpeizer, B.G.; Clearfield, A.; Heising, J.M. New families of supermicroporous metal oxides: The link between zeolites and mesoporous materials. Chem. Commun. 2005, 18, 2396-2398. [CrossRef]

20. Song, K.; Guan, J.; Wang, Z.; Xu, C.; Kan, Q. Post-treatment of mesoporous material with high temperature for synthesis super-microporous materials with enhanced hydrothermal stability. Appl. Surface Sci. 2009, 255, 5843-5846. [CrossRef]

21. Gu, F.N.; Wei, F.; Yang, J.Y.; Lin, N.; Lin, W.G.; Wang, Y.; Zhu, J.H. New strategy to synthesis of hierarchical mesoporous zeolites. Chem. Mater. 2010, 22, 2442-2450. [CrossRef]

22. Kim, J.C.; Ryoo, R.; Opanasenko, M.V.; Shamzhy, M.V.; Cejka, J. Mesoporous MFI zeolite nanosponge as a high-performance catalyst in the Pechmann condensation reaction. ACS Catal. 2015, 5, 2596-2604. [CrossRef]

(C) 2020 by the authors. Licensee MDPI, Basel, Switzerland. This article is an open access article distributed under the terms and conditions of the Creative Commons Attribution (CC BY) license (http://creativecommons.org/licenses/by/4.0/). 